\title{
Changes in integument structure during the imaginal molt of the honey bee*
}

\author{
Moysés Elias-NeTo, Michelle P.M. SoARES, Márcia M.G. BITONDI \\ Departamento de Biologia, Faculdade de Filosofia, Ciências e Letras de Ribeirão Preto - \\ Universidade de São Paulo, Avenida Bandeirantes 3900, 14040-901 Ribeirão Preto, SP, Brazil
}

Received 3 April 2008 - Revised 2 September 2008 - Accepted 29 September 2008

\begin{abstract}
The changing pattern of developing cuticle and associated epidermis is described during the imaginal molt in the honey bee. Observations began immediately after the pupal molt, and included histological analyses of the integument during apolysis and the subsequent deposition and differentiation of the adult cuticle. Apolysis coincides with a marked increase in the thickness and reorganization of the epidermal layer, reflecting changes in cell structure. The epidermis remains thickened during the period of cuticle deposition, suggesting intense biosynthetic activity, but turns into a very thin layer during cuticle differentiation, clearly indicating that secretory activity for cuticle formation is terminating. The thoracic cuticle differentiates earlier and becomes thicker than the abdominal. The observed changes in integument structure provide insights that permit an improved physiological characterization for staging pupal and pharate adult development.
\end{abstract}

Apis mellifera / integument / metamorphosis / adult cuticle / exoskeleton

\section{INTRODUCTION}

The recent publication of the genome sequence of the honey bee Apis mellifera L. (The Honeybee Genome Sequencing Consortium, 2006), and the finding that it has a smaller number of genes encoding cuticular proteins than the Drosophila, Anopheles and Tribolium genomes, raised questions about the evolution of exoskeleton in social insects. The smaller number of cuticle protein genes in the honey bee has been tentatively assigned to its social organization within a protective colony, a feature perhaps linked to the development of a less complex cuticle. Honey bee genome data are now motivating studies on the molecular structure of the integument, i.e., epidermis and associated cuticle. Three novel cuticle protein genes were recently identified in the honey bee

Corresponding author: M. Elias-Neto, meliasneto@pg.ffclrp.usp.br

* Manuscript editor: Yves Le Conte genome (Kucharsky et al., 2007) in addition to the 28 sequences previously annotated by The Honeybee Genome Sequencing Consortium (2006). We showed that expression of one of these cuticular protein genes, AmelCPR14, was shown to be associated with metamorphic and imaginal molting events for cuticle renewal and differentiation (Soares et al., 2007).

Studies on the expression and regulation of cuticle protein genes need to be linked to macro and microscopic structural changes that the integument undergoes during molting cycles. Such knowledge is important in the context of functional genomics. However, there are not detailed studies illustrating the transformations occurring in the morphology of the epidermis as the adult cuticle is synthesized and deposited. The exception is a publication by Thompson (1978), who used traces and dots in simple diagrams to represent the progressive deposition of cuticle layers in developing bees. The current study was set up to histologically describe changes in integument 
during a molting cycle. We chose to focus on the pupal-imaginal molt because it involves the remarkable events of cuticle pigmentation and intense sclerotization needed for the differentiation of the adult exoskeleton. Microscopical information obtained from honey bee integument sections was contrasted with macroscopic, progressive external modifications, especially pigmentation occurring in the cuticle. The derived information associates the changing morphological pattern of the integument with pupal-imaginal molt events, and is of interest for studies on molecular aspects of exoskeleton morphogenesis, now facilitated by the publication of the honey bee genome. In this context we also discuss a proposal to standardize the terminology applied to the different stages of the honey bee life cycle.

\section{MATERIALS AND METHODS}

\subsection{Honey bees}

Developing and adult honey bee workers were collected from Africanized stocks in hives maintained at the experimental apiary of the São Paulo University in Ribeirão Preto, SP, Brazil. Developmental stages and phases were identified following criteria established by Michelette and Soares (1993). Briefly, the pupal and successive pharate adult phases were removed from sealed brood cells and categorized in seven groups according to the absence, or presence and progressive intensification of eye color and thoracic pigmentation. Adults were collected soon after they emerged from brood cells. Pupae, pharate adults and adults were used to investigate the morphological changes in integument showed in Figures 1-4, and also to illustrate Figure 5, which also includes 5th instar larvae and developing pharate pupae. Larvae in the 5th instar were collected from sealed brood cells at the end of the spinning phase, when their guts were completely empty. Initial pharate pupae were recognized by the presence of exuvial fluid in the head region. The next phase (intermediary pharate pupae) was identified by the presence of cephalic and thoracic appendages, perceptible underneath the outermost larval cuticle. The presence of a wrinkled and opaque cuticle and of a marked constriction delimitating thorax and abdomen was used as a reference to identify the last pharate pupal phase.

\subsection{Integument preparations for light microscopy}

\subsubsection{Histological sections}

Histological sections were prepared using integument dissected from the dorsal-medial region of the thorax, and from the medial region of the 3rd abdominal tergite of worker bees. At least three specimens from each sequential phase of the pupalimaginal development were dissected for histological sections, and the best integument preparations are presented. After brief rinses with Ringer saline $\left(\mathrm{NaCl} 0.17 \mathrm{M} ; \mathrm{KCl} 0.01 \mathrm{M} ; \mathrm{CaCl}_{2} 0.003 \mathrm{M}\right)$, fat body adhering to the epidermis was removed as far as possible, and integuments were kept for 24 hours in cold $\left(4{ }^{\circ} \mathrm{C}\right)$ fixative (4\% paraformaldehyde in $0.1 \mathrm{M}$ phosphate buffer, $\mathrm{pH}$ 7.3). Next, integuments were dehydrated in a graded ethanol series $(70,80$, 90 and $95 \%$ ethanol in water, v/v), and then infiltrated for 24 hours and embedded in methacrylate resin (Historesin, Leica). Sections of $5 \mu \mathrm{m}$ were stained with methylene blue and basic fuchsin for 3 minutes, followed by a rapid washing in distilled water (Hartfelder and Steinbrück, 1997). Sections were mounted in Entellan (Merck) and examined and photographed using an Axioskop II photomicroscope (Zeiss).

\subsubsection{Whole mounts}

Thoracic and abdominal integuments were dissected from the bee dorsum, gently rinsed in Ringer saline, cleaned of excess fat body and mounted on slides using pure glycerol. These whole mounts were immediately examined and photographed. At least three specimens from each developmental phase in the pupal-imaginal molting interval were dissected and the best whole mounts preparations are shown.

\section{RESULTS}

\subsection{Deposition and maturation of the adult cuticle in the honey bee}

Sections of the thoracic and abdominal integument (Figs. 1 and 2) show the gradual changes undergone by cuticle and underlying epidermis during a complete molting cycle. The schematic drawings shown on the left and 


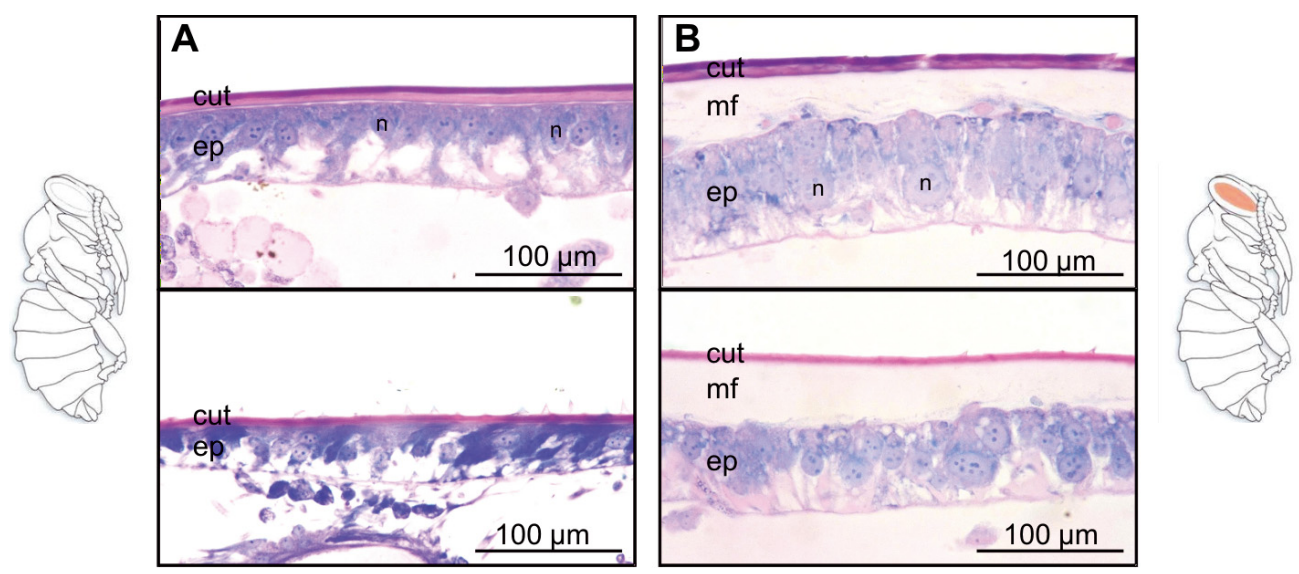

Figure 1. Integument of the honey bee (A) before and (B) after imaginal apolysis. Thoracic (above) and abdominal (below) integument sections of a white-eyed pupa (represented at the left) and of a pink-eyed pharate adult (at the right). Schematic representations of pupa and pharate adult modified from Costa et al. (2006). cut - cuticle; ep - epidermis; $\mathrm{n}$ - nucleus; $\mathrm{mf}$ - molting fluid.

right sides of the histological sections represent the developmental stages from which the integument pieces were dissected.

During pupal ecdysis, the shedding of the larval cuticle causes the externalization of the soft and unpigmented pupal cuticle that overlies a thick epidermis. In this stage, the nuclei of the epidermal cells are localized apically, and in the basal cytoplasm appear large clear areas, perhaps representing stores of secretions to be used in the synthesis of molting fluid and/or cuticular compounds (Fig. 1A). A few hours later, pigments begin to appear in the eyes of the developing pupae, changing from a white to a light pink coloration (compare schemes of developing bees at the sides of Fig. 1). This coincides with the separation of the pupal cuticle from the epidermis, or apolysis. In consequence, a space filled with molting fluid is created between the detached pupal cuticle and the epidermis (Fig. 1B). Apolysis occurs simultaneously with a reorganization in the epidermal layer which now forms a pseudostratified epithelium that begins to synthesize the adult cuticle. From this moment to adult ecdysis the developing adult is still enclosed by a pupal cuticle. Therefore, it is frequently referred to as a pharate adult.

The clear areas previously concentrated at the basal cytoplasm of the epidermal cells in newly ecdysed pupae (Fig. 1A) are now pulverized throughout the apical cytoplasm of epidermis in pink-eyed pharate adults, suggesting transport of material from the basal to the apical cytoplasm (Figs. 2A, B arrows). The thoracic epidermis becomes very thick in pinkeyed pharate adults. The abdominal epidermis is thinner than the thoracic and still retains most of the clear areas in the basal cytoplasm (Fig. 2A). Deposition of the adult cuticle is initiated in pink-eyed pharate adults (Fig. 2A). In the next developmental phase, dark-pinkeyed pharate adults, a well-defined adult cuticle now covers the thoracic epidermis. The deposition of the thoracic cuticle is advanced compared to the abdominal one (Fig. 2B). A mass of myocytes (Fig. 2B) appears below the thoracic epidermis.

The thickness of the thoracic cuticle increases as development goes on, although the abdominal cuticle still remains relatively thin (Fig. 2C). The pharate adult now has intensely pigmented brown eyes (scheme of a brown-eyed pharate adult shown at the left of Fig. 2C). Newly formed imaginal striated muscles are abundant below the epidermis of thoracic sections.

In the thoracic cuticle, the onset of pigmentation (represented by a colored mark on the thorax of a pharate adult at the left side 

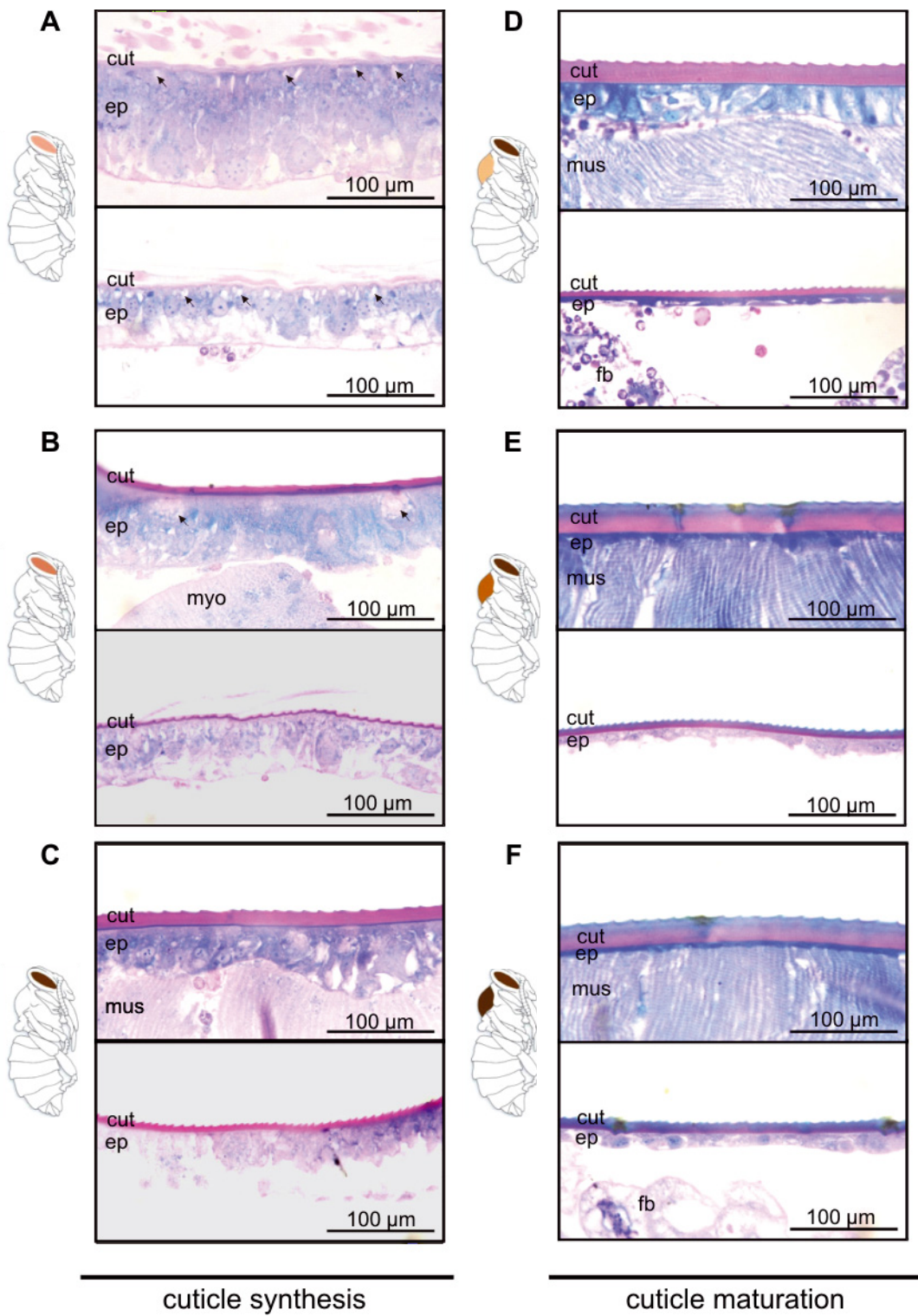

Figure 2. Adult cuticle deposition and maturation in developing pharate adults. Sections of thoracic and abdominal integuments are shown above and below in each figure, respectively. Beginning (A) and progression (B, C) of cuticle deposition, and maturation (D-F). Pharate adults from which integuments were dissected for histological analyses are schematized at the laterals of figures. Cuticle deposition occurs in early pharate adult phases when developmental progress is marked by a change in eye color, from pink, to dark pink, and finally to the definitive brown color (early pharate adult development represented at the left of figures A-C). Cuticle maturation occurs during the late phases of pharate adult development, coinciding with cuticle pigmentation (late pharate adults with a mark on the thoracic cuticle representing the progression of cuticle pigmentation are shown at the left of figures D-F). Arrows indicate the clear areas in the apical cytoplasm (see item 3.1). cut - cuticle; ep - epidermis; mus - muscle; fb - fat body; myo myocytes. 

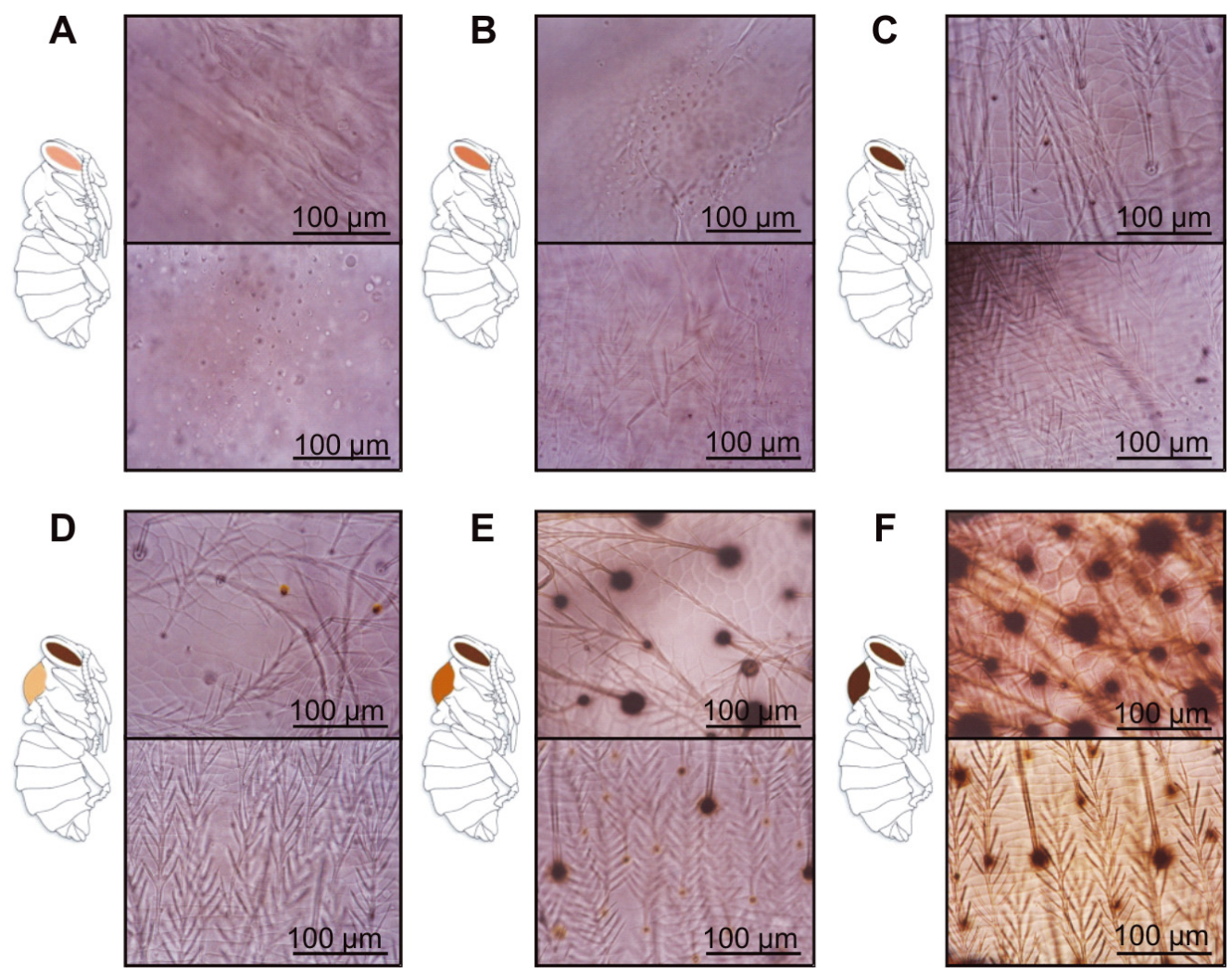

Figure 3. Pattern of cuticle pigmentation during pharate adult development. Pharate adults from which the integuments were dissected for whole mount preparation are schematized at the left of whole mounts. Thoracic and abdominal integuments are shown above and below in each figure, respectively. Cuticle of pharate adults in initial development $(\mathrm{A}-\mathrm{C})$ is devoid of pigments. Pigment formation initiates earlier in thorax than in abdomen (D-F) at the second half of the pharate adult development. Branched setae protrude from setal sockets in the thoracic and abdominal cuticles.

of Fig. 2D) apparently marks the transition from cuticle deposition to its differentiation. As thoracic cuticle pigmentation intensifies (as represented in the schemes at the left side of Figs. 2E, F), the epidermis becomes very thin, mainly in the thorax, where it can hardly be visualized. Epidermis is also converted into a thin layer in the abdominal region (Figs. 2E, F).

Thoracic muscles that initially were only loosely associated with the integument (Fig. 2D), now become tightly connected (Figs. 2E, F). At the end of the pharate adult development (Figs. 2E, F), the thoracic cuticle is characterized by two differentially stained layers (pink and blue) suggesting distinct chemical compositions. Both layers are part of the procuticle, which is the major cuticle component formed mainly by interlaced proteins and chitin.

Figure 3 shows the onset and progress of cuticle pigmentation in whole mount preparations. Between the pink-eyed (Figs. 3A, B) and the early brown-eyed pharate adult phases (Fig. 3C), pigments could not yet be discerned macroscopically in the thoracic or abdominal cuticle, but they became detectable in the thoracic cuticle of the subsequent pharate adult phase (Fig. 3D), with a rapid increase in the amount of pigmented areas as development 

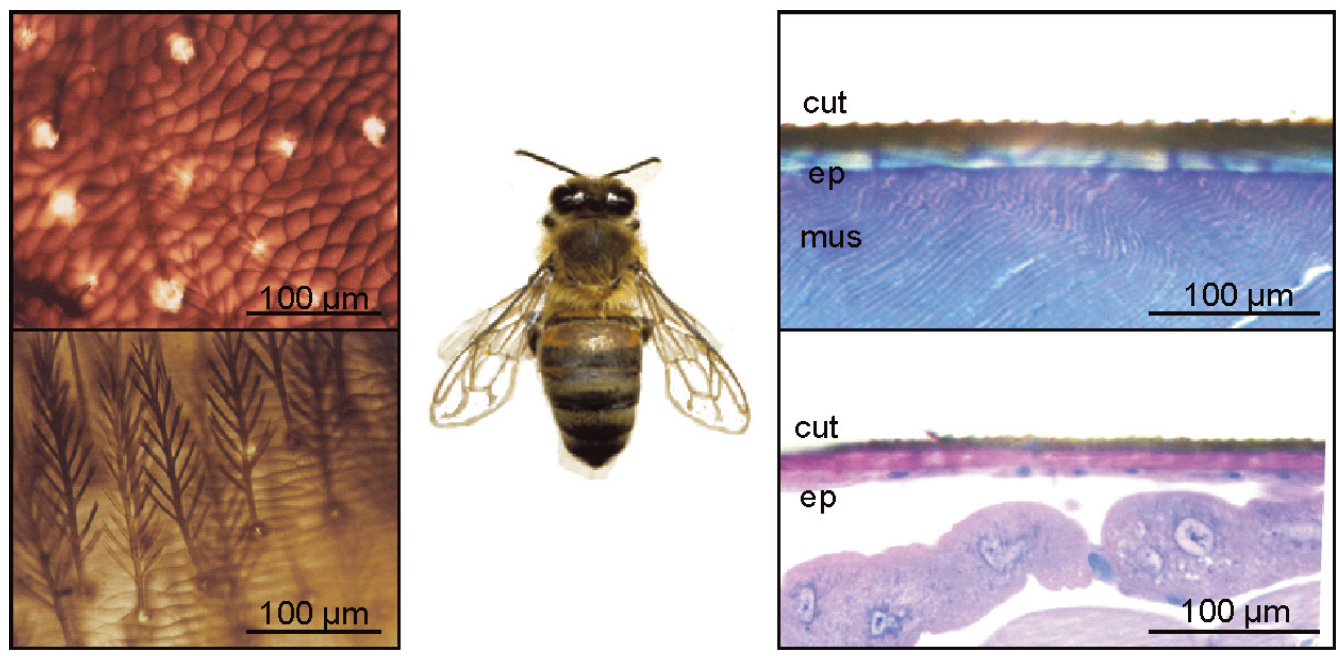

Figure 4. Pattern of cuticle pigmentation and sclerotization in adults. Whole mount preparations (at the left) and histological sections (at the right) of thoracic (above) and abdominal (below) integuments of an adult worker bee (shown in the center of the figure). cut - cuticle; ep - epidermis; mus - muscle.

advances (Figs. 3E, F). Pigmentation initiates later in abdominal cuticle, only when the thorax is already darkened (compare Figs. 3D, E).

Cuticle tanning also continues in the honey bee after adult ecdysis. Whole mount preparations of adult cuticle (Fig. 4, left side) clearly show that it is much darker in comparison to the cuticle of later pharate adults (Fig. 3F). In histological sections of the adult cuticle we could observe the presence of a very dark layer (Fig. 4, right side), not seen in the cuticle of later pharate adults (Fig. 2F).

\section{DISCUSSION}

\subsection{Changes in honey bee integument during a molting cycle}

The temporal sequence of integument sections revealed considerable changes in epidermis and cuticle structure during the imaginal molt. Pupal epidermis contains large clear areas in the basal cytoplasm, but following pupal/adult apolysis, clear inclusions also appeared pulverized throughout the apical cytoplasm. Studies carried out in the epidermis of a lepidopteran, Calpodes ethlius, revealed apical and basal peptide trafficking routes for secretion into the cuticle and hemolymph, respectively. However, it appears that basally localized peptides may be firstly secreted apically, and then endocytosed into vesicles to be transported via a basal route to the hemolymph (Locke, 2003). Our preparations do not make possible to identify the nature and destination of the material forming the clear areas in the epidermal cell cytoplasm. Considering that a new cuticle is being deposited following apolysis, it is possible that such material is being transported from the basal to the apical cytoplasm to be used in cuticle formation. Alternatively, as this material is abundantly present in epidermal cells before and during formation of the ecdysial space, it is possible that it is discharged to fill this space as molting fluid. At a molting stage that precedes the detachment of epidermis in the crab Carcinus maenas, similar clear areas appear at the apices of the epidermal cells. They were identified as membrane-bounded large vacuoles opened at the cell surface, and their profiles strongly suggested that they contribute to molting fluid formation (Compère et al., 1998).

Our results show that apolysis is marked by an increase in the thickness of the epidermal layer, which also change cell shape. In fact, in insects in general, apolysis has been associated 


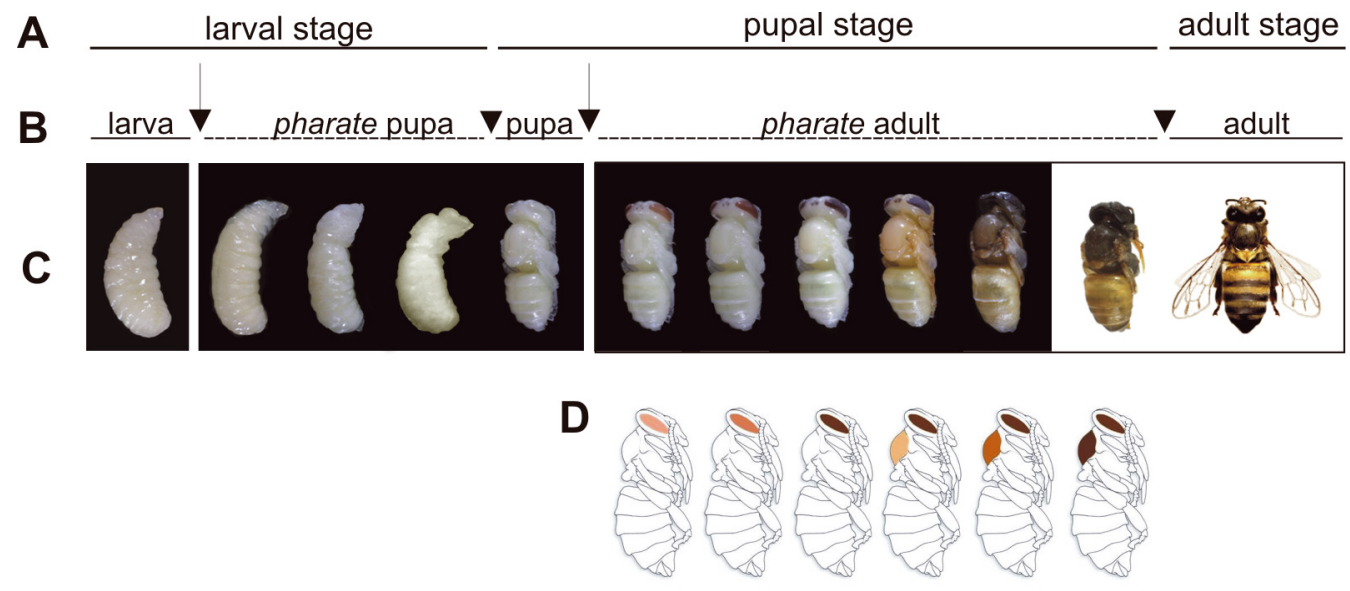

Figure 5. Metamorphic and imaginal molts in the honey bee. (A) Life stages (larval, pupal and imaginal) are delimited by ecdyses (arrowheads) and defined by the outermost cuticle; (B) Ontogenetic instars (larva, pupa and adult) is delimited by apolyses (arrows) and defined by the innermost cuticle (adhered to the epidermis). During the pharate period, which is extended from apolysis to ecdysis, the new cuticle is synthesized and differentiates underneath the cuticle of the preceding instar; (C) Photographs of the developmental series: larva, pharate pupae, pupa, pharate adults and adult; (D) Schematic representation of pharate adults showing the morphological attributes (eye color and thoracic pigmentation) used to recognize successive developmental phases. To facilitate comparisons, pharate adult representations are the same shown in the sides of Figures 1, 2 and 3.

with mitosis and expansion of the volume of epidermal cells (Hepburn, 1985). Following the period of cuticle deposition during the first half of pharate adult development in worker bees, the epidermis becomes very thin indicating that its biosynthetic activity for cuticle formation is subsiding. This change in morphological pattern reflects the transition from the period of biosynthesis of the adult cuticle to its differentiation, which is visually marked by a progressive pigmentation.

As cuticle is deposited in the dark-pinkeyed pharate adults, a mass of muscle cell precursors (myocytes) appears in the thoracic sections. In brown-eyed pharate adults, muscle formation is in progress and fibers derived from myocytes come in contact with the epidermis for attachment on the cuticle. The thoracic integument sections of developing pharate adults (see Fig. 2) show the rebuilding of the thoracic musculature in substitution of the larval, which is completely histolyzed during honey bee metamorphosis (Oertel, 1930). Muscle fibers are not seen in abdominal (see Fig. 2) sections because histo- logical preparations did not include the intersegmental grooves where the abdominal longitudinal muscle fibers are attached (Snodgrass, 1956), but only the medial region of the segment (3rd tergite), deprived of attached muscles.

Cuticle is a multilayered structure formed by an outermost envelope (which serves to protect the epidermis from molting fluid enzymes during cuticle renewal), an intermediary chitin-free epicuticle and the most internal procuticle, the thickest layer, made up mainly of proteins and chitin (Locke, 2001; Willis et al., 2005). This layer is in part secreted during the pharate stage, and in part after ecdysis. Pre-ecdysially secreted procuticle is termed exocuticle, and the post-ecdysial secretion forms the endocuticle (Andersen et al., 1995). Our integument preparations do not permit us to distinguish the thinner envelope and the epicuticle, but the pink and blue layers seen in histological sections (Figs. 1,2) are both components of the procuticle. The great increase in procuticle thickness during honey bee pharate adult development indicates that a 
very major part is deposited before adult ecdysis, mainly during the first half of pharate development.

We observed that the process of procuticle melanization, which accompanies the hardening (sclerotization) of the newly forming exoskeleton, continues and intensifies even after the eclosion of the adult. This is in accordance with studies on chemical and mechanical properties of the honey bee cuticle (Thompson and Hepburn, 1978; Andersen et al., 1981), which demonstrated that both deposition of materials, including melanin, and reactions for cuticle stabilization continue well into the adult stage. However, when the degree of sclerotization was estimated by measuring the amounts of ketocatechols released from abdominal cuticle by acid hydrolysis, the highest amount was found in the late pharate adults, and these levels did not increase after eclosion (Andersen et al., 1981). Although ketocatechol quantification is a useful method to measure sclerotization, it only quantifies ketocatechols derived from the sclerotizing precursors $\mathrm{N}$ acetyldopamine and $\mathrm{N}-\beta$-alanyldopamine. It is likely that other molecules have a role as cuticle sclerotization precursors (Andersen, 2005).

In the honey bee, the rates of deposition and maturation of the thoracic and abdominal cuticles are very distinct. Thoracic cuticle is deposited earlier than the abdominal one, and rapidly forms a thick layer whereas the abdominal cuticle is deposited more slowly, and is thin. Thoracic and abdominal cuticles have different origins and this may explain their distinct rate of development and maturation. In Drosophila melanogaster, it is well established that imaginal discs originate the thoracic cuticle and histoblast nests in abdomen give rise to the abdominal cuticle (Fristrom and Fristrom, 1993). The fact that the honey bee abdominal cuticle is thinner than the thoracic one was previously observed by Thompson (1978) who illustrated cuticle layers deposition using simple schematic diagrams. The sequential histological sections shown here detail the transformations occurring in epidermis as the adult cuticle is deposited and differentiates, thus adding new information on the changing pattern of epidermis and cuticle during pupal and pharate adult development.

\subsection{Considerations on the terminology used to describe honey bee life cycle stages}

The life cycle of the honey bee has been described under different perspectives, all having in common suggestions or proposals of criteria for the recognition of sequential phases of postembryonic development (Bertholf, 1925; Oertel, 1930; Myser, 1954; Snodgrass, 1956; Jay, 1963; Thompson, 1978; Rembold et al., 1980; Michelette and Soares, 1993; Nunes-Silva et al., 2006). Notwithstanding, there is still some confusion and inconsistency regarding the terminology used to describe honey bee stages. Based on the sequential integument sections and whole mounts shown in the current work, Figure 5 includes a proposal to make such descriptions more uniform or at least clearer. This figure associates the sequential changes in external morphology with the events (apolysis and ecdysis) of pupal and imaginal molts and explains the terminology used here to discriminate the developmental phases of the honey bee worker. It is clear in this figure that the term stage is related to the time interval between two subsequent ecdyses (indicated by arrowheads in Fig. 5), i.e., the shedding of that portion of the outermost cuticle which cannot be broken down by chitinases and other enzymes from the molting fluid. The stage (larval, pupal or adult) is defined by the type of the outermost cuticle. Consequently this definition of stage does not take into consideration that major components of the cuticle of the subsequent stage are being synthesized beneath and under the protective cover of the old cuticle.

Apolysis signalizes the beginning of the synthesis of a new cuticle and, for many insect physiologists it is a more appropriate parameter to delimitate developmental phases. This is clearly expressed by Jones (1978), for whom subsequent apolyses (indicated by arrows in Fig. 5) delimitate an instar, which is defined by the innermost (new) cuticle adhering to the epidermis, even while the instar is still hidden 
(pharate) beneath the old cuticle that soon will be shed. Although apolysis is a key event in arthropod molting cycle, its utilization as a marker of instar transition has been largely neglected in the honey bee literature, especially when referring to the pupal-adult transition. Thompson (1978) pioneered the use of apolysis as a marker to separate pupal from adult development in honey bees. As show in Figure 5, we also consider the importance of apolysis and favor the use of the term "pharate" because it best describes the postapolytic stages when a new cuticle is being synthesized beneath the old one.

In the larval-pupal molt, the period between the separation (apolysis) of the old (larval) cuticle from the epidermis until the shedding of this cuticle is frequently called prepupal. One can also propose the utilization of the term "pharate pupa", instead of the inappropriate "pre-pupa". According to Snodgrass (1956): "The so-called propupa... is merely the pupa in its early developmental stages within the moulted skin of the larva" ("moulted" is the term that the author used to inform that apolysis has already occurred). Later, this was repeated "When the last larval cuticle is moulted, the insect is no longer a larva, though before ecdysis it is still within the larval cuticle" (Snodgrass, 1960). Except for Thompson (1978), who used "pharate pupa" to describe this phase, all other authors listed above (in the first paragraph of this section) have preferred to use the terms prepupa or pro-pupa. Jay (1963) actually used both terms, prepupa and pharate pupa synonymously.

The pupal-adult transition is more complicated in terms of cuticle events, since apolysis of the pupal cuticle from the underlying epidermis already occurs when eye coloration is gradually changing from white. From a cuticle point of view, the pink-eyed pupa would thus mark the end of the pupal instar, being followed by the pharate adult instar during which the new imaginal cuticle is laid down and gradually gains in pigmentation. However, this developing adult still covered by the pupal cuticle is frequently designated as a pupa.

Following this line of argument, the term pharate adult should be preferred over the term pupa to designate developing adult bees still involved by the pupal cuticle.

As mentioned above, apolysis and the onset of the synthesis of the adult cuticle were verified in pink-eyed pharate adults. Precisely at this developmental phase (then called pink-eyed pupae) a peak of ecdysteroids was demonstrated in hemolymph using radioimmunoassay (Pinto et al., 2002). Therefore, a morphological character, pink eyes, was definitively associated with the beginning of the production of a new cuticle, an event triggered by elevated ecdysteroid levels.

The data presented here and the discussion of terminology applied to the stages of the honey bee life cycle should be useful to future studies on physiology, biochemistry, genetics, and functional genomics related to molting events and adult exoskeleton formation.

\section{ACKNOWLEDGEMENTS}

Financial support was provided by a grant from FAPESP (05/03926-5) and by a FAPESP fellowship to M. Elias-Neto (05/03301-5). We thank K. Hartfelder for critically reading a previous version of the manuscript. We also thank Z.L.P. Simões for interesting suggestions regarding histology techniques, and L.R. Aguiar for technical assistance in the apiary.

Modifications dans la structure du tégument au cours de la mue imaginale de l'Abeille domestique.

Apis mellifera / métamorphose / exosquelette / cuticule / tégument / histologie

Zusammenfassung - Änderungen in der Integumentstruktur im Verlauf der Imaginalhäutung der Honigbiene. Zur Unterstützung von Untersuchungen zur differentiellen Expression von Cuticula-Proteine kodierenden Genen beschreiben wir hier die Dynamik der Bildung der Adultcuticula. Wir konzentrieren uns hier auf die Häutung von der Puppe zur Imago, da diese bemerkenswerte Prozesse der Cuticulapigmentierung und Sklerotisierung beinhaltet, die für die Differenzierung des adulten Exoskeletts wichtig sind. Integumentstücke wurden aus dem Thorax und dem Abdomen entnommen, in Ringerlösung gewaschen und in Paraformaldehyd fixiert. Nach der Entwässerung 
wurden sie in Methacrylharz eingebettet. Histologische Schnitte wurden mittels Methylenblau und basischem Fuchsin gefärbt. Wir fertigten auch Ganzpräparate an, die in Glyzerin montiert wurden.

Epidermiszellen von frischgehäuteten weissäugigen Puppen zeigen einen apikal gelagerten Kern und ein basalseitiges Cytoplasma mit klaren Bereichen (Abb. 1A). Das eigentliche Puppenstadium ist sehr kurz, da die Apolyse bereits einsetzt, sobald die Augen der Puppen eine leicht rosa Färbung zeigen (Abb. 1B) Mit der Apolyse geht eine Umorganisation der Epidermis in ein pseudostratifiziertes Epithel und dem Beginn der Synthese der Adultcuticula einher. Während die thorakale Epidermis von rosaäugigen Pharatadulten bereits vergleichsweise dick ist, ist die abdominal Epidermis noch dünn und wenig differenziert (Abb. 2A).

Die klaren Bereiche, die in frischgehäuteten Puppen zunächst auf die Basalseite der Epidermiszellen beschränkt waren sind jetzt auch im apikalen Bereich klar zu sehen, was auf Materialtransportvorgänge von der basalen zur apikalen Epithelseite hindeutet (Pfeile in Abb. 2A und B). In Puppen mit dunkelrosa gefärbten Augen ist die Ablagerung der thorakalen im Vergleich zur abdominalen Cuticula bereits weit fortgeschritten (Abb. 2B). Bei braunäugigen Pharatadulten ist der Thorax von einer dicken Cuticula bedeckt (Abb. 2C), während auch hier die abdominal Cuticula noch dünn ist. (Abb. 2C). Unter der thorakalen Cuticula ist jetzt bereits die gestreifte Imaginalmuskulatur zu sehen, und der Beginn der Cuticulapigmentierung markiert den Übergang von der Phase der Cuticulaablagerung zur Differenzierung. Einhergehend mit der Cuticulapigmentierung (Abb. 2E und F) wird die Epidermis dünner, nicht nur im Thorax sondern auch im Abdomen, was auf das Ende der Biosynthesephase der Cuticulabildung hinweist (Abb. 2E und F). Die Thoraxmuskulatur, die zunächst nur lose mit dem Integument assoziiert war (Abb. 2D), gewinnt jetzt einen festen Anschluss (Abb. 2E und F).

Der Beginn und Verlauf der Cuticulapigmentierung konnte in den Ganzpräparaten verfolgt werden (Abb. 3). In der Cuticula von rosa-äugigen oder frühen braunäugigen Pharatadulten ist in der Cuticula noch keine Pigmentierung zu sehen (Abb. 3 A-C). Die Pigmentierung beginnt in der Cuticula in der darauffolgenden pharatadulten Phase (Abb. 3D) und zeigt eine rasche Ausweitung der pigmentierten Bereiche (Abb. 3E und F). In der abdominalen Cuticula beginnt die Pigmentierung später. Sowohl die Ganzpräparate als auch die histologischen Schnitte (Abb. 4, linke und rechte Seite) zeigen klar, dass die Cuticula der Imagines stärker pigmentiert ist als die der späten Pharatadultphase (Abb. 2F und 3F).

In dieser Zeitverlaufsserie zeigen die histologischen Schnitte klar die weitreichenden Veränderungen in der Integumentstruktur im Häutungszyklus auf und liefern damit neue Informationen über die Dynamik der Veränderungen der Epidermisstruktur und zum Cuticulaaufbau vor und während der Apolyse und in den darauffolgenden Phasen der pharatadulten Entwicklung, die mit der adulten Ecdysis endet. Die Veränderung in der Integumentstruktur geht einher mit der Entwicklung der äusseren Morphologie und den Häutungsereignissen. Diese Information ist von Interesse für Untersuchungen zu genetischen, biochemischen und physiologischen Aspekten des Aufbaus des adulten Exoskeletts. Die gegenwärtige Arbeit enthält ausserdem einen Vorschlag zur Vereinheitlichung der Terminologie, die den Verlauf des Häutungszyklus bei Bienen beschreibt.

\section{Apis mellifera / Integument / Metamorphose / Adultcuticula / Exoskelett}

\section{REFERENCES}

Andersen S.O. (2005) Cuticular sclerotization and tanning, in: Gilbert L.I., Iatrou K., Gill S.S. (Eds.), Comprehensive Molecular Insect Science, Elsevier Pergamon, Australia, Vol. 4, pp. 145-170.

Andersen S.O., Thompson P.R., Hepburn H.R. (1981) Cuticular sclerotization in the honeybee (Apis mellifera adansonii), J. Comp. Physiol. 145, 17-20.

Andersen S.O., Hojrup P., Roepstorff P. (1995) Insect cuticular proteins, Insect Biochem. Mol. Biol. 25, 153-176.

Bertholf L.M. (1925) The moults of the honeybee, J. Econ. Entomol. 18, 380-384.

Compère P., Thorez A., Goffinet G. (1998) Fine structural survey of old cuticle degradation during preecdysis in two European atlantic crabs, Tissue Cell 30, 41-56.

Costa C., Ide S., Simonka C.E. (Eds.) (2006) Insetos imaturos, Holos, Ribeirão Preto, SP, Brazil.

Fristrom D., Fristrom J.W. (1993) The metamorphic development of the adult epidermis, in: Bate M., Arias A.M. (Eds.), The development of Drosophila melanogaster, Cold Spring Harbor Laboratory Press, New York, Vol. 2, pp. 843-897.

Hartfelder K., Steinbrück G. (1997) Germ cell cluster formation and cell death are alternatives in caste-specific differentiation of the larval honey bee ovary, Invertebr. Reprod. Dev. 31, 237-250.

Hepburn H.R. (1985) Structure of the integument, in: Kerkut G.A., Gilbert L.I. (Eds.), Comprehensive Insect Physiology, Biochemistry and Pharmacology, Pergamon Press, Oxford, Vol. 3, pp. 1-58.

Jay S.C. (1963) The development of honeybees in their cells, J. Apic. Res. 2, 117-134.

Jones J.C. (1978) A note on the use of the terms instar and stage, Ann. Entomol. Soc. Am. 71, 491-492.

Kucharski R., Maleszka J., Maleszka R. (2007) Novel cuticular proteins revealed by the honey bee genome, Insect Biochem. Mol. Biol. 37, 128-134. 
Locke M. (2001) The Wigglesworth lecture: insects for studying fundamental problems in biology, J. Insect Physiol. 47, 495-507.

Locke M. (2003) Surface membranes. Golgi complexes, and vacuolar systems, Annu. Rev. Entomol. 48, 1-27.

Michelette E.R.F., Soares A.E.E. (1993) Characterization of preimaginal developmental stages in Africanized honey bee workers (Apis mellifera L), Apidologie 24, 431-440.

Myser W.C. (1954) The larval and pupal development of the honeybee, Apis mellifera Linnaeus, Ann. Entomol. Soc. Am. 47, 683-711.

Nunes-Silva P., Gonçalves L.S., Francoy T.M., De Jong D. (2006) Rate of growth and development time of africanized honey bee (Apis mellifera) queens and workers during ontogenetic development, Braz. J. Morphol. Sci. 23, 325-332.

Oertel E. (1930) Metamorphosis of the honeybee, J. Morphol. 50, 295-339.

Pinto L.Z., Hartfelder K., Bitondi M.M.G., Simões Z.L.P. (2002) Ecdysteroid titers in pupae of highly social bees relate to distinct modes of caste development, J. Insect Physiol. 48, 783-790.

Rembold H., Kremer J.-P., Ulrich G.M. (1980) Characterization of postembryonic developmental stages of the female castes of the honey bee, Apis mellifera L., Apidologie 11, 29-38.
Snodgrass R.E. (1956) Anatomy of the honey bee, Cornell University, Ithaca.

Snodgrass R.E. (1960) Some words and their ways in entomology, Proc. Entomol. Soc. Wash. 62, 265270.

Soares M.P.M., Elias-Neto M., Simões Z.L.P., Bitondi M.M.G. (2007) A cuticle protein gene in the honeybee: expression during development and in relation to the ecdysteroid titer, Insect Biochem. Mol. Biol. 37, 1272-1282.

The Honeybee Genome Sequencing Consortium (2006) Insights into social insects from the genome of the honeybee Apis mellifera, Nature 443, 931-949.

Thompson P.R. (1978) Histological development of cuticle in the worker honeybee, Apis mellifera adansonii, J. Apic. Res. 17, 32-40.

Thompson P.R., Hepburn H.R. (1978) Changes in chemical and mechanical properties of honeybee (Apis mellifera adansonii L.) cuticle during development, J. Comp. Physiol. 126, 257-262.

Willis J.H., Iconomidou V.A., Smith R.F., Hamodrakas S.J. (2005) Cuticular proteins, in: Gilbert L.I., Iatrou K., Gill S.S. (Eds.), Comprehensive Molecular Insect Science. Elsevier Pergamon, Australia, Vol. 4, pp. 79-109. 